\title{
BROMATOLOGICAL COMPOSITION OF PALM KERNEL MEAL ACCORDING TO ITS ORIGIN AND PRODUCTION PERIODS POTENTIAL USE OF PALM KERNEL MEAL IN ANIMAL FEED
}

\author{
EDISON MAZÓN PAREDES*; MARCELINO HERRERA RODRÍGUEZ ${ }^{\star \star}$; CARLOS MAZÓN PAREDES*; \\ ANTÓN GARCÍA MARTÍNEZ;; MANUEL DELGADO PERTIÑEZ ${ }^{\ddagger \ddagger}$ and JOSÉ LUIS GUZMÁN GUERRERO
}

\begin{abstract}
Ecuador has a variety of agroindustrial by-products, which can be used in animal feed, although their nutritional values are often unknown. The objective of this study was to evaluate bromatological composition of palm kernel cake (PKC) in samples from two palm oil extraction plants in two areas (Quevedo and Santo Domingo) and two production periods (August and September). Random samples were taken weekly with two repetitions for a total of 64 samples. Dry matter $(D M)$, ash, organic matter $(O M)$, crude protein $(C P)$, ether extract (EE), crude fibre (CF), nitrogen-free extract (NFE), neutral detergent fibre (NDF), acid detergent fibre (ADF), acid detergent lignin ( $A D L)$, calcium, phosphorus, crude energy (CE) and metabolisable energy (ME) were determined. OM (62.92\%) and EE (10.10\%) content were higher at the Quevedo plant, while CF (23.84\%) and $A D L(24.66 \%)$ were higher at the Santo Domingo plant. The sampling period affected DM (98.58\%), CF (23.98\%) and ADL (23.78\%) content, which were higher in September, while EE $(10.87 \%)$ and phosphorus $(0.44 \%)$ were higher in August. For CP, NFE, NDF, ADF, ash, calcium, CE and ME, interaction was observed between the two factors studied. It was concluded that most of the parameters analysed depend on the place of origin or the extraction season, or interaction between the two factors.
\end{abstract}

Keywords: Elaeis guineensis Jacq 1763 L, agroindustrial by-products, proximal analysis, production period, Ecuador.

Received: 18 November 2019; Accepted: 5 April 2020; Published online: 7 October 2020.

\section{INTRODUCTION}

The high cost of traditional energy products used for animal feed has sparked a search for new products

\footnotetext{
School of Zootechnical Engineering,

Faculty of Livestock Sciences,

Quevedo State Technical University,

$\mathrm{Km} \mathrm{61/2}$ via a El Empalme cruce a Mocache,

120501 Quevedo, Los Rios, Ecuador.

E-mail: emazonp@hotmail.com

** Department of Aquaculture, Agricultural and Fisheries Research and Training Institute (IFAPA),

$\mathrm{Km} \mathrm{4,} \mathrm{Carretera} \mathrm{EI} \mathrm{Rompido-Punta} \mathrm{Umbria,}$

21450 Cartaya, Huelva, Spain.

₹ Faculty of Veterinary Medicine,

University of Cordoba,Campus de Rabanales,

s/n 14071 Cordoba, Spain.

㧊 Department of Agroforestry Sciences,

Higher Technical School of Agronomic Engineering,

Sevilla University, 41013 Sevilla, Spain.

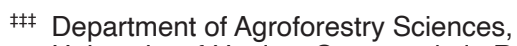

University of Huelva, Campus de la Rabida,

21819 Palos de la Frontera, Huelva, Spain.
}

and the evaluation of their nutritional potential. One of these crops is oil palm (Elaeis guineensis Jacq. $1763 \mathrm{~L})$. Palm kernel cake (PKC) is obtained when it is processed.

Vegas et al. (2016) reported that the cultivation of African palm in Ecuador began in the area of La Concordia in the 1950s. The plantations were established with material from Elaeis guineensis Deli Dura. Subsequently, at the Santo Domingo Experimental Station of the National Institute of Agricultural Research (INIAP), Ecuador, through the African Palm Programme, the material was improved and local Pisiferous plants were segregated and used to obtain the INIAP Tenera hybrid, using local palm (Dura) mothers and (Pisifera) fathers.

The palm-growing area of Ecuador is located in four regions; the main one is in the western area known as the Quevedo-Santo Domingo-Quinindé triangle. In 2013, palm cultivation totalled 244574 ha and domestic production was 2.93 million tonnes of fresh fruit, meaning that for each hectare of crop, 
an average of $12 \mathrm{t}$ was produced (MAGP, 2013). The Esmeraldas region has $61.5 \%$ of the cultivated area and $64.8 \%$ of total production, Los Ríos has $14 \%$ of the cultivated area and $9.7 \%$ of production, Santo Domingo de los Tsáchilas has $6.6 \%$ of the cultivated area and $7.9 \%$ of production and Pichincha has $6.68 \%$ of the cultivated area and $5.55 \%$ of production (Varela, 2010).

Alimon (2004) reported that proximal analyses of PKC showed that it can be classified as an energy food because its protein content is only $16 \%$ to $18 \%$, which would include it as a protein food, and its chemical composition is very similar to that of corn gluten or rice bran. PKC supplies protein and energy, but is considered more as a source of protein, sufficient to meet the needs of most ruminants. PKC protein content varies between $10.0 \%$ and $19.8 \%$ (Yeong and Mukherjee, 1983; Rahim et al., 2010; Nuzul, 2013). PKC also contains a large amount of crude fibre (CF), from $13 \%$ to $20 \%$ (Alimon, 2004).

Sharmila et al. (2014) reported that the solvent extraction method provides efficient oil extraction, leaving PKC with a higher CF content. Moreover, the use of different varieties of oil palm, different methods of separating the husk from the seed and different processing methods before the extraction of the oil can also affect the (CF) values of PKC. Further, PKC nutritional values have been extensively studied and described by Alimon (2004) and Dairo and Fasuyi (2007).

PKC is mainly used in cattle feed, although it has also been used for poultry, pigs and fish due to its nutritional content: dry matter (DM) (88.0\%-94.5\%), crude protein (CP) $(14.5 \%-19.6 \%)$, CF $(13.0 \%-20.0 \%)$, ether extract (EE) $(5.0 \%-8.0 \%)$, ash $(3.0 \%-12.0 \%)$, nitrogen-free extract (NFE) $(46.7 \%-58.8 \%)$, neutral detergent fibre (NDF) $(66.8 \%-78.9 \%)$.

According to Alimon (2004), the metabolisable energy (ME) of PKC for ruminants is 2.5-2.6 Mcal $\mathrm{kg}^{-1}$, which is considered suitable for most ruminants. PKC is commonly used as an energy source for both beef cattle and dairy cattle. This author has reported that for poultry, the $\mathrm{ME}$ in PKC is quite low (1.6-1.8 Mcal kg-1). The ME for ducks also ranges from 1.7-1.9 Mcal kg-1. Pork ME is higher than that of poultry $\left(2.4-2.5 \mathrm{Mcal} \mathrm{kg}^{-1}\right)$, but its intake may decrease if the inclusion rate exceeds $30 \%$.

Agroindustrial by-products are processing plant waste; their nutritional value is usually low, and they generate an environmental problem for the industry. Moreover, their nutritional value is often unknown (Vargas and Zumbado, 2003). It has been reported that in Costa Rica and other tropical countries, there is limited knowledge about the composition and proper use of agroindustrial by-products that are or could be used by the livestock feed industry (Vargas, 2000). This biological variability, the poor description of each of the by-products used as animal feed in the different countries, the practice of providing information as averages without indicating the number of samples or the variability in composition, contribute to making the interpretation and use of published information difficult and confusing (Yeong et al., 1981; Belyea et al., 1989; Arosemena et al., 1995).

Wing Keong (2005) reports that studies have been carried out at the Universiti Sains Malaysia, Pulau Pinang, Malaysia (USM) to improve the nutritional value of palm almond cake in relation to protein content. In addition, one of the ways to increase the protein content of palm almond cake is through fermentation with a fungus (Trichoderma koningii), which virtually doubles the protein content of palm almond cake from approximately 17\%-32\% raw protein.

The starting hypothesis for this work was that PKC has a high nutritional value and could be used as animal feed in several physiological stages, and that the place of origin and season of production of this PKC could affect its bromatological composition. Therefore, the general objective was to evaluate bromatological composition of PKC in samples from two palm oil extraction plants with different areas of origin (the cantons of Quevedo and Santo Domingo) and two production periods (August and September).

\section{MATERIALS AND METHODS}

\section{Characteristics of the Areas of Origin of the By-product Used}

Quevedo is located at $1^{\circ} 20^{\prime} 30^{\prime \prime}$ south latitude and $79^{\circ} 28^{\prime} 30^{\prime \prime}$ west longitude in a subtropical area. The predominant soil type is derived from volcanic ash, which provides good fertility and high moisture retention. It is located at $74 \mathrm{~m}$ above sea level. This canton is between the last Andean folds and the coastal plains (INMH, 2018).

The province of Santo Domingo de los Tsáchilas has a total area of $3857 \mathrm{~km}^{2}$. Its geographical position is defined by the coordinates: $0^{\circ} 40^{\prime}$ north longitude, and the average elevation is $655 \mathrm{~m}$ above sea level. It is located on the outer flanks of the western cordillera of the Andes, and a tropical rainy climate predominates throughout the province. The dry season is characterised by low temperatures between July and December, and the rainy season is characterised by high temperatures between January and May (INMH, 2018).

\section{Samples and Sampling}

Random samples of PKC were taken during the continuous production process in August and September 2016, at two palm oil extraction plants, 
one located in Quevedo and the other in Santo Domingo, Ecuador. The samples weighing $1 \mathrm{~kg}$ and were taken twice a week with two replicates each, for a total of 64 analysed samples ( 2 oil extraction plants $\times 2$ production periods $\times 4$ week $\times 2$ samples/ week $\times 2$ replicates/week).

\section{Chemical-bromatological Analysis of the By-products}

Chemical analyses of the samples were carried out at the Santa Catalina Laboratories of INIAP in Izabamba ( $0^{\circ} 21^{\prime} \mathrm{S}, 78^{\circ} 33^{\prime} \mathrm{W}$ and $3058 \mathrm{~m}$ elevation), during August and September 2016. The sample (experimental unit) was mixed carefully on a flat surface using the quarters method, in which portions of the two opposite quarters were taken and mixed again, and the operation was repeated as many times as necessary until the desired quantity was obtained. The final weight of the sample for the analysis was $1 \mathrm{~kg}$ of PKC. The samples were homogenised and placed in air-tight plastic bags and labelled. Before analysis, the samples were crushed and passed through a $1 \mathrm{~mm}$ diameter sieve in a Willey mill. DM (method 934.01), ash (method 942.05), EE (method 920.39), CP (method 984.13) and $\mathrm{CF}$ (method 978.10) were determined according to AOAC methods (AOAC, 2006). Also, NFE was determined by difference, $\% \mathrm{NFE}=\% \mathrm{DM}-(+\% \mathrm{CP}$ $+\% \mathrm{CF}+\%$ Ash $+\% \mathrm{EE})$.

The total nitrogen $(\mathrm{N})$ values were determined by the Kjeldahl procedure, which converts $\mathrm{N}$ into $\mathrm{CP}$ by multiplying by the factor 6.25 . The analyses for NDF, acid detergent fibre (ADF) and acid detergent lignin (ADL) were carried out according to Van Soest et al. (1991) and were expressed without residual ash. All fibre fractions were analysed in a Fibretec 1030 Hot Extractor (Tecator AB, Sweden). The fat content was measured by extraction with petroleum ether (boiling point $40^{\circ} \mathrm{C}$ to $60^{\circ} \mathrm{C}$ ) in a Soxtec System 1040 extraction unit (FOSS Tecator $A B$, Sweden). Crude energy (CE) was determined by means of an adiabatic calorimetric pump (Parr model). Calcium was determined by the indirect redox titration method and phosphorus was found by colorimetric determination in a sodium bicarbonate solution using a Bausch and Lomb Spectronic 20 Colorimeter. The ME was calculated using the methodology of mathematical equations (Gasa and Castrillo, 1992; Aguilera, 2001).

\section{Statistical Treatment}

The results of the bromatological composition of the samples were analysed by means of an analysis of variance (ANOVA) using the general linear model (GLM) of the SPSS statistical package for Windows (version 24.0, IBM Corp., Armonk New York, USA).
The model considered the fixed origin $(P)$ and month $(M)$ factors and interaction between them.

The mathematical model is shown below:

$Y i j=\mu+P i+M j+(P \times M) i j+\varepsilon i j$

where:

Yij - observations for dependent variables

$\mu$ - overall mean

$\mathrm{Pi}$-'i-th' effect of the levels of factor ( $P$, origin), $i=1,2$

$\mathrm{Mj}$-' $\mathrm{i}$-th' effect of the levels of factor ( $M$, month), $j=1,2$

$(P \times M) i j$ - effect of the interaction between the levels of factor $P$ and the levels of factor $M$.

عij - random effect (experimental error).

If a significant effect of interaction between the main factors is found, the means of the different groups will undergo a multiple comparison of means using the Tukey test.

\section{RESULTS}

Table 1 shows the bromatological composition of $\mathrm{PKC}$ for samples taken in Quevedo and Santo Domingo, Ecuador. DM, phosphorus and CE content did not show significant differences $(p>0.05)$ between the areas of Quevedo and Santo Domingo. OM, CP, EE, NFE, ash and ME contents were higher $(p<0.001)$ in PKC samples from the canton of Quevedo; however, the calcium content, $\mathrm{CF}, \mathrm{NDF}, \mathrm{ADF}$ and ADL were higher for the canton of Santo Domingo.

Regarding the sampling season, Table 1 shows that for most of the parameters studied (DM, NFE, $\mathrm{CF}, \mathrm{ADF}, \mathrm{ADL}$, calcium, $\mathrm{CE}$ and $\mathrm{ME}$ ), the values were higher (at least $\mathrm{p}<0.05$ ) in September, except for $\mathrm{CP}, \mathrm{EE}$, ash and phosphorus, which were higher (at least $\mathrm{p}<0.05$ ) in August. No differences were found between the two sampling months for organic matter $(\mathrm{OM})$ and NDF ( $\mathrm{p}>0.05)$.

A significant effect was found in the interaction between origin and month (at least for $\mathrm{p}<0.05$ ) for the variables $\mathrm{CP}, \mathrm{NFE}, \mathrm{NDF}, \mathrm{ADF}$, ash, calcium, $\mathrm{CE}$ and ME (Table 1). Table 2 and Figures 1 to 4 show the separation test of the means for each of these parameters. Due to the nature of the interaction for NFE, ADF, ash and ME (ordered interaction, Ott and Longnecker, 2010), only the main effects were interpreted above. It can be seen how samples taken in August had a CP and CE higher contents when they came from the Quevedo area, whereas for samples taken in September, the content was 
TABLE 1. BROMATOLOGICAL COMPOSITION OF PALM KERNEL CAKE ACCORDING TO THE MONTH OF SAMPLING AND THE ORIGIN (Quevedo and Santo Domingo)

\begin{tabular}{|c|c|c|c|c|c|c|c|c|}
\hline \multirow{2}{*}{$\begin{array}{l}\text { Composition } \\
(\%, \text { base } \mathrm{DM})^{*}\end{array}$} & \multicolumn{2}{|c|}{ Origin (P) } & \multicolumn{2}{|c|}{ Month (M) } & \multirow{2}{*}{ SEM } & \multicolumn{3}{|c|}{ Significance ${ }^{* *}$} \\
\hline & $\begin{array}{c}\text { Quevedo } \\
\mathrm{N}=16\end{array}$ & $\begin{array}{l}\text { Santo Domingo } \\
\qquad \mathbf{N}=\mathbf{1 6}\end{array}$ & $\begin{array}{l}\text { August } \\
\mathrm{N}=16\end{array}$ & $\begin{array}{l}\text { September } \\
\qquad N=16\end{array}$ & & $\begin{array}{c}\text { Fixed origin } \\
\text { (P) }\end{array}$ & $\begin{array}{l}\text { Month } \\
\text { (M) }\end{array}$ & PxM \\
\hline Dry matter (\%) & 98.42 & 98.42 & 98.26 & 98.58 & 0.04 & NS & $* * *$ & NS \\
\hline Organic matter $(\%)$ & 65.92 & 61.52 & 62.86 & 64.59 & 0.63 & $* * *$ & NS & NS \\
\hline Crude protein $(\%)$ & 19.07 & 17.68 & 20.05 & 16.70 & 0.35 & $* * *$ & $* * *$ & $* * *$ \\
\hline Ether extract $(\%)$ & 10.10 & 9.64 & 10.87 & 8.87 & 0.20 & $* * *$ & $* * *$ & NS \\
\hline NFE $(\%)$ & 46.70 & 33.74 & 37.07 & 43.36 & 1.31 & $* * *$ & $* * *$ & $* * *$ \\
\hline Crude fibre $(\%)$ & 22.74 & 23.84 & 22.70 & 23.88 & 0.19 & $* * *$ & $* * *$ & NS \\
\hline NFD $(\%)$ & 81.74 & 83.16 & 82.43 & 82.48 & 0.28 & ** & NS & $* * *$ \\
\hline $\operatorname{ADF}(\%)$ & 60.98 & 64.79 & 61.51 & 64.26 & 0.54 & $* * *$ & $* * *$ & $* * *$ \\
\hline $\operatorname{ADL}(\%)$ & 19.75 & 24.66 & 20.63 & 23.78 & 0.68 & $* * *$ & $* * *$ & NS \\
\hline Ash (\%) & 5.26 & 4.23 & 4.75 & 4.73 & 0.09 & $* * *$ & $* * *$ & $* * * *$ \\
\hline Calcium (\%) & 2.87 & 2.97 & 2.85 & 2.99 & 0.02 & $* * *$ & $* * *$ & $* * *$ \\
\hline Phosphorus (\%) & 0.43 & 0.41 & 0.44 & 0.41 & 0.01 & NS & * & NS \\
\hline CE (Mcal kg $\left.{ }^{-1} \mathrm{DM}\right)$ & 4.90 & 4.73 & 4.71 & 4.91 & 0.05 & NS & * & * \\
\hline ME (Mcal kg-1 DM) & 2.16 & 1.47 & 1.53 & 2.10 & 0.08 & $* * *$ & $* * *$ & $* * *$ \\
\hline
\end{tabular}

Note: *DM - dry matter; NFE - nitrogen-free extract; NDF - neutral detergent fibre; ADF - acid detergent fibre; ADL - acid detergent lignin; CE - crude energy; ME - metabolisable energy. The ME was calculated using the following equations (Gasa and Castrillo, 1992; Aguilera, 2001): $\mathrm{ME}(\mathrm{kJ})=15.66 \times \mathrm{MOD}(\mathrm{g})$ and MOD $(\%)=107.01-0.963 \times \mathrm{ADF}(\%$, DM); where MOD is the digestible organic matter. SEM - standard error of mean.

${ }^{* *} \mathrm{NS}$ - not significant $(\mathrm{p}>0.05) ;{ }^{*} \mathrm{p}<0.05 ;{ }^{* *} \mathrm{p}<0.01 ;{ }^{* * *} \mathrm{p}<0.001$

similar in samples from both areas (Figures 1 and 2). For NDF the opposite occurred; for samples taken in August, NDF content was higher in the Santo Domingo area and no differences were found between the two origins for September (Figure 3). Calcium content was higher for samples from Santo Domingo in September, while in August there were no differences between the two sources (Figure 4).

\section{DISCUSSION}

African palm plants grown in Ecuador are genetic materials that are adapted to the specific conditions of the country; they are highly productive varieties and are resistant to disease and provide long-term benefits. All these have been achieved thanks to trials in international research and production institutes: Palm Elit SAS, Institut de Recherche pour Les Huiles et Oléagineux (IRHO) and Centre de Coopération Internationale en Recherche Agronomique Pour Le Développement (CIRAD) with the joint participation of Ecuadorian geneticists who gathered and interpreted the results obtained in trials in different localities in order to create and develop highly productive seeds adapted to local conditions.

Industrial processing of oil palm has also been improved in recent years and the bromatological content (CP and $\mathrm{CE}$ ) of this by-product has increased and its appearance has improved. Given the improved nutritional bromatological content, it could be used for both ruminant and non-ruminant animals (Alimon, 2004; Dairo and Fasuyi, 2007).

The bromatological composition of PKC nutrients varies greatly according to data found in the literature (Babatunde et al., 1975; Nwokolo et al., 1976; Fetuga et al., 1977; Hutagalung et al., 1981; Yeong et al., 1981; Onwudike, 1986; Lekule et al., 1990; Novus International Inc., 1994; Vargas and Zumbado, 2003). The DM content produced in the Quevedo and Santo Domingo areas showed values that were higher than those described in the literature (Alimon, 2004) (88.0\%-94.5\%) and Vargas and Zumbado (2003) stated that 90\% of African palm cooking flour was extracted by solvents (APCFES) and $93.80 \%$ of African palm cooking flour was extracted by press (APCFEM).

The $\mathrm{CP}$ obtained in the study areas was higher than those registered by Alimon (2004) (14.5\%$19.6 \%$ ) and higher than those reported by Vargas and Zumbado (2003), at $12.5 \%, 15.1 \%$ and $17.5 \%$ APCFE, respectively. The ash content obtained in the study areas was lower than that recorded by Alimón (2004) (3.0\%-12.0\%), and similar to those registered by Vargas and Zumbado (2003) in Costa Rica at $4.10 \%$. These results could be due to the oil palm variety grown in Malaysia and Costa Rica is different from the variety planted in Ecuador, and 
also to the different soil and climatic conditions in these different studies.

The calcium reported in the study areas was higher than that found by Alimon (2004) $(0.21 \%$ $0.34 \%$ ) and Vargas and Zumbado (2003), at $0.29 \%$ APCFES and $0.28 \%$, respectively. The phosphorus content in the study areas was lower than that reported by Alimon (2004) $(0.48 \%-0.71 \%)$ at $0.50 \%$.

TABLE 2. EFFECTS OF (origin $x$ month) ON THE BROMATOLOGICAL COMPOSITION OF PALM KERNEL CAKE IN DIFFERENT SAMPLES FROM OIL EXTRACTORS IN QUEVEDO AND SANTO DOMINGO AREAS

\begin{tabular}{|c|c|c|c|c|}
\hline \multirow{4}{*}{$\begin{array}{l}\text { Chemical } \\
\text { composition } \\
\text { (\% DM } \\
\text { basis) }^{*}\end{array}$} & \multicolumn{4}{|c|}{ Origin** } \\
\hline & \multirow{2}{*}{\multicolumn{2}{|c|}{$\begin{array}{c}\text { Quevedo } \\
\text { Month }\end{array}$}} & \multirow{2}{*}{\multicolumn{2}{|c|}{$\begin{array}{c}\text { Santo Domingo } \\
\text { Month }\end{array}$}} \\
\hline & & & & \\
\hline & $\begin{array}{c}\text { August } \\
(\mathrm{n}=8)\end{array}$ & $\begin{array}{l}\text { September } \\
\quad(\mathrm{n}=8)\end{array}$ & $\begin{array}{c}\text { August } \\
(\mathrm{n}=8)\end{array}$ & $\begin{array}{l}\text { September } \\
(\mathrm{n}=8)\end{array}$ \\
\hline NFE $(\%)$ & $42.30^{\mathrm{b}}$ & $51.10^{\mathrm{a}}$ & $31.85^{\mathrm{d}}$ & $35.63^{c}$ \\
\hline $\operatorname{ADF}(\%)$ & $58.48^{\mathrm{b}}$ & $63.49^{\mathrm{a}}$ & $64.53^{\mathrm{a}}$ & $65.04^{\mathrm{a}}$ \\
\hline Ash (\%) & $5.25^{\mathrm{b}}$ & $4.27^{\mathrm{a}}$ & $4.25^{\mathrm{c}}$ & $4.20^{\mathrm{d}}$ \\
\hline $\begin{array}{r}\text { ME (Mcal } \\
\left.\mathrm{kg}^{-1} \mathrm{DM}\right)\end{array}$ & $1.81^{\mathrm{b}}$ & $2.52^{\mathrm{a}}$ & $1.25^{\mathrm{d}}$ & $1.69^{c}$ \\
\hline
\end{tabular}

Note: *DM - dry matter; NFE - nitrogen-free extract; NDF - neutral detergent fibre; ADF - acid detergent fibre; ADL - acid detergent lignin; CE - crude energy; ME - metabolisable energy. The ME was calculated using the following equations (Gasa andCastrillo, 1992; Aguilera, 2001): ME $(\mathrm{kJ})=15.66 \times \mathrm{MOD}(\mathrm{g})$ and $\operatorname{MOD}(\%)=107.01-0.963 \times$ $\operatorname{ADF}(\%, \mathrm{DM})$; where MOD is the digestible organic matter. ${ }^{* *}$ Means with different letters in the same row and factor indicate significant differences (at least $\mathrm{p}<0.05$ ).

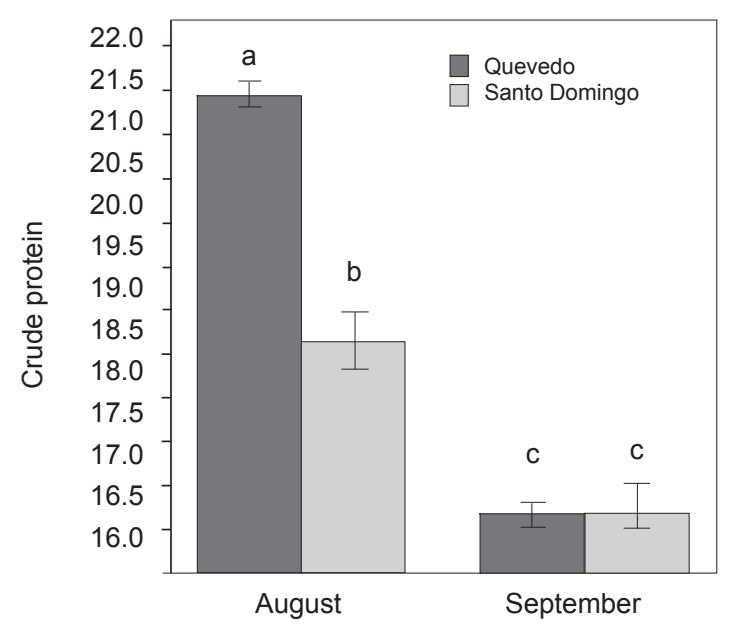

Production months

Figure. 1. Interaction of origin $(P)$ and month $(M)$ on crude protein (CP) content [\% dry matter (DM) basis] for different samples from palm oil extractors in the Quevedo and Santo Domingo areas. Values presented are the means with standard error bars. ${ }^{a, b, c}$ Indicate significant differences between mean values $(p<0.05)$

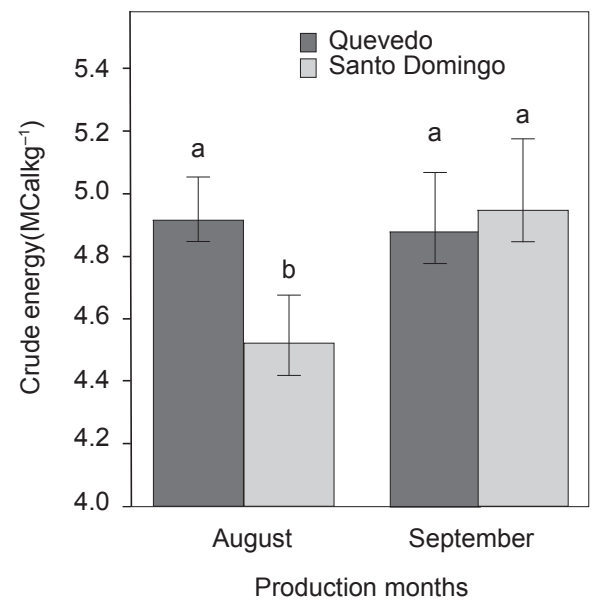

Figure 2. Interaction of origin $(P)$ and month $(M)$ for crude energy $(C E)$ conten [Mcal kg-1 dry matter (DM)] in different samples from palm oil extractors in the Quevedo and Santo Domingo areas. Values presented are the means with standard error bars. ${ }^{a, b}$ Indicate significant differences between mean values $(p<0.05)$.

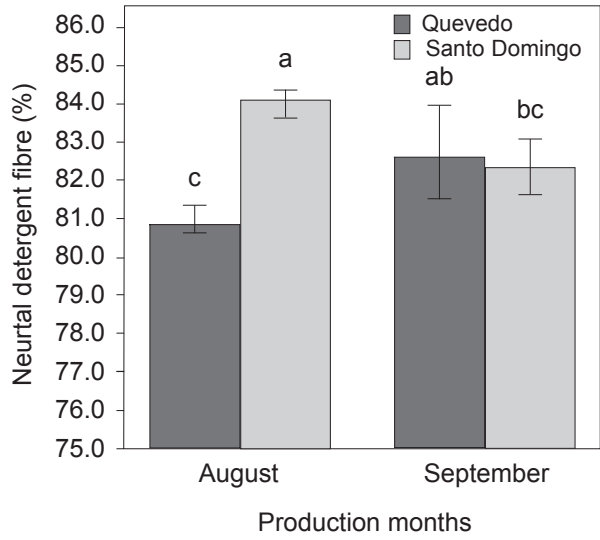

Figure. 3. Interaction of origin $(P)$ and month $(M)$ on neutral detergent fibre (NDF) content [\% dry matter (DM) basis] for different samples from palm oil extractors in the Quevedo and Santo Domingo areas. Values presented are the means with standard error bars. ${ }^{a, b, c}$ Indicate significant differences between mean values $(p<0.05)$.

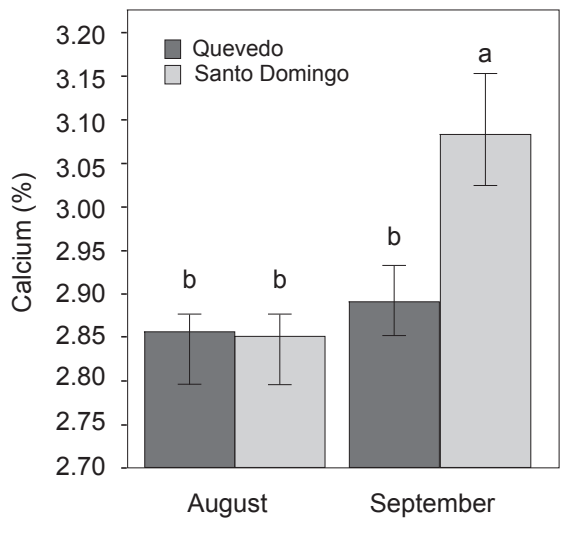

Production months

Figure 4. Interaction of origin $(P)$ and month $(M)$ for the calcium content [\% dry matter (DM) basis] for different samples from palm oil extractors in the Quevedo and Santo Domingo areas. Values presented are the means with standard error bars. ${ }^{a, b}$ Indicate significant differences between mean values $(p<0.05)$. 
The variability of the bromatological composition results of PKC samples in the experiment was possibly due to the different ages of the plants chosen for harvesting the fruit (Fairhurst, 2010).

It may also be due to several environmental factors that affect African palm production and diminish its productive potential and fresh fruit quality. Some of these environmental factors include latitude, altitude, rainfall, topography, and soil texture and structure, and act indirectly on the different physiological processes of the plant, while others do so directly, such as solar radiation, photoperiod, temperature, water and soil fertility (Munévar, 2004).

In the study areas, CF values were higher than those reported by Alimon (2004) (13.0\%-20.0\%) and also higher than those found by Vargas and Zumbado (2003) (18.40\%-18.51\%, APCFES and APCFEM, respectively). Values obtained from NDF were higher than those reported by Alimon (2004) $(66.8 \%-78.9 \%)$ and also those reported by Vargas and Zumbado (2003) at $69.73 \%$ APCFES and $66.82 \%, 69.73 \%$ APCFEM, respectively. ADF values were higher than those obtained by Vargas and Zumbado (2003) at $43.70 \%$ APCFES and 66.82 APCFEM, respectively. The NFE obtained in the locality studied, when compared with results obtained by Alimon (2004) (46.7\%-58.8\%) and Vargas and Zumbado (2003) (55.6\% APCFES and $48.35 \%$ APCFEM) were lower.

The increased number of cell wall components observed in the canton of Santo Domingo was due to walnut shell (endocarp) residues, which remain in the industrial process. This higher concentration of parietal components, together with lower fat content, affects the energy content of this by-product and explains the lower values found for ME.

The effect of locality was favourable for OM, $\mathrm{CP}, \mathrm{EE}, \mathrm{NFE}$, ash and ME content because the values found in Quevedo were higher than those of Santo Domingo due to the different environmental and soil factors. ME data for Quevedo and Santo Domingo are lower than those observed by Alimon (2004), for ruminants $\left(2.5-2.6 \mathrm{Mcal} \mathrm{kg}^{-1}\right)$, poultry (1.6 -1.8 Mcal kg-1), ducks (1.7-1.9 Mcal kg ${ }^{-1}$ ), and pigs (2.4-2.5 Mcal kg-1).

The oil palm industrialisation process at the two plants, in Quevedo and Santo Domingo de los Tsáchilas, was similar (Urrueta, 2009), so the variability of the bromatological composition analyses cannot be attributed to the industrial process, but it could be due to different soil types and climatic variability in the two study areas (Romero et al., 2007).

Pántano et al. (2013) reported that soil water response is a function of the variability of the monthly accumulated precipitation. Futhermore, potential monthly evapotranspiration is a product of the interaction between the soil and the atmosphere and contributes greatly to the characterisation of the climate system. In particular, precipitation and temperature are major variables in determining the moisture situation of the soil, which in turn results in a greater or lesser oil palm production during the different months of the year due to variations in temperature and monthly precipitation in the different localities.

In addition to this, the particular environmental conditions of the site where each plant is located could determine palm growth, development and production characteristics. For oil palm, as for all plant species, the action of a climatic factor is variable and its influence will depend on the magnitude of the environmental phenomenon and the development phase of the crop (Romero et al., 2007).

Regarding the sampling period, for most of the parameters studied (DM, NFE, CF, ADF, ADL, calcium, $\mathrm{CE}$ and $\mathrm{ME}$ ) the values were higher in September, except CP, EE, ash and phosphorus, which were higher in August. In addition to the factors mentioned above, there were other causes of productive variation in the areas studied. Estupiñan et al. (2013) stated that there are other reasons why areas where oil palm is produced show productive variability, which include: different hybrids, different planting ages, different types of phytosanitary problems, different modes of fertilisation, which could cause this productive variability in each study area, in addition to climatic, soil and ecological factors.

\section{CONCLUSION}

The area of origin of PKC did not influence DM and phosphorus content; however, in the Quevedo area, higher OM, EE, ash, NFE, and ME and lower ADF were found. The production periods of the oil palm industrial process affected the bromatological composition of most of the parameters studied because the values obtained for DM, NFE, CF, ADF, ADL and ME were higher in September, while values of EE, Ash and phosphorus were higher in August. Meanwhile, the CP, CE, NDF and calcium content of palm kernel cake was different in each area of origin depending on when the extraction took place, such that CP and CE were higher in Quevedo only in August and NDF and calcium were higher in Santo Domingo in August and September, respectively.

\section{RECOMMENDATION}

Due to the variability of its bromatological composition, depending on its origin and time of extraction, PKC must be analysed before use as complementary food for animals. It is recommended 
that a sampling study be conducted in the rainy season (January to April) and in the dry season (June to August), in the tropical zone of the Ecuador. Finally, it is recommended that a fermentation process be carried out in solid form with fungi, especially with the one identified as Trichoderma koningii on palm almond cake to increase the protein content, since this methodology has good potential, according to a report by $\mathrm{Ng}$ et al. (2002), as it doubled the protein content of raw palm seed cake from $17 \%$ to $32 \%$.

\section{ACKNOWLEDGEMENT}

The research was supported by the Graduate Department of the State Technical University of Quevedo, with supported from Fourth Notary of the canton Quevedo Los Rios, Ecuador and INIA-FSE. We would like to thank to the reviewers for their valuable contribution to this article.

\section{REFERENCES}

Aguilera, J F (2001). Aportaciones al conocimiento de la nutrición energética de pequeños rumiantes, con particular referencia al ganado caprino. Archivos de Zootecnia., 50: 565-596.

Alimon, A R (2004). The nutritive value of palm kernel cake for animal feed. J. Oil Palm Res. Vol. 40: 12-16.

Arosemena, A; Depeters, E and Fadel, J (1995). Extent of variability in nutrient composition within selected by-products feedstuffs. Anim. Feed Sci. Technol., 54: 103-120.

AOAC (2006). Official Methods of Analysis (Horwitz, $\mathrm{W}$ and Latimer, $\mathrm{G}$ eds.). $18^{\text {th }}$ Edition, Gaithersburg., p. 1-68.

Babatunde, M; Fetuga, G; Odumosu, $\mathrm{O}$ and Oyenuga, V (1975). Palm kernel meal as the major protein concentrate in the diets of pigs in the tropics. J. Sci. Food Agric., 26: 1279-1291.

Belyea, R; Esteevens, B; Restrepo, R and Clubb, A (1989). Variation in composition of by-products feeds. J. Dairy Sci., 72: 2339-2345.

Dairo, F A S and Fasuyi, A O (2007). Evaluation of fermented palm kernel meal and fermented copra meal proteins as substitute for soyabean meal protein in laying hens diets. J. Cent. Eur. Agr., 9: 33-47.

Estupiñan, G; Santacruz, L and Cristancho, A (2013). Caracterización de las variables de crecimiento, niveles foliares y de rendimiento en dos materiales genéticos de palma OxG y DxP en diferentes edades de desarrollo de la plantación Guaicaramo S.A. Revista Palmas., 34: 99-108.

Fairhurst, T (2010). Algunas prácticas clave de manejo para máximo rendimiento en cultivos maduros de palma de aceite. Revista Palmas., 31(1): 45-46.

Fetuga, B; Babatunde, G and Oyenuga, V (1977). The value of palm kernel meal in finishing diet for pigs. J. Sci. Food Agric., 26: 1279-1291.

Gasa, J and Castrillo, C (1992). Criterios de utilización de subproductos agroindustriales en la alimentación de rumiantes. Hojas divulgativas 13/91. Ministerio de Agricultura, Pesca y Alimentación, Madrid. 24 pp.

Hutagalung, R; Mahyuddin, $\mathrm{M}$ and Jalabudin, $\mathrm{S}$ (1981). Feed for farm animals from the oil palm. National Workshop on Oil Palm By-products Utilization. https:/ / www.cabdirect.org/cabdirect/ abstract/20053053501, accessed on 16 July 2018.

INMH (2018). Meteorological Yearbook No. 52-2012. National Institute of Meteorology and Hydrology, Republic of Ecuador. Www.serviciometeorologico. gob.ec, accessed on 24 November 2018.

Lekule, F; Jorgensen, H; Fernandez, J and Just, A (1990). Nutritive value of some tropical feedstuffs for pig. Chemical composition, digestibility and metabolizable energy content. Anim. Feed Sci. Technol., 28: 91-101.

MAGP (2013). Short-term survey program No. AG86-II-2013. Ministry of Agriculture, Livestockand Fisheries, Republic of Ecuador. https:/ / contenido. bce.fin.ec/documentos / PublicacionesNotas / Catalogo/Encuestas / Coyuntura / Integradas / etc201302.pdf, accessed on 22 February 2019.

Munévar, F (2004). Criterios agroecológicos útiles en la selección de tierras para nuevas siembras de palma de aceite en Colombia. Revista Palmas., 28(2): 148-164.

Ng, W K; Lim, H K; Lim, S W and Ibrahim, O (2002). Nutritive value of palm kernel meal pretreated with enzyme or fermented with Trichoderma koningii (Oudemans) as a dietary ingredient for red hybrid tilapia (Oreochromis sp.). Aqua Resc., 33: 1119-1207.

Novus International Inc. (1994). Raw Material Compendium a Compilation of Worldwide Data Sources. Second edition, Bruselas por Novus Europe. $511 \mathrm{pp}$. 
Nuzul, I (2013). Characteristics of Malaysian palm kernel and its products. J. Oil Palm Res. Vol. 25: 245252.

Nwokolo, E; Bragg, D and Kitts, W (1976). The availability of amino acids from palm kernel, soybean, cottonseeds and rapeseeds meal for the growing chick. J. Poult. Sci., 55: 2300-2304.

Onwudike, O (1986). Palm kernel meal as a feed for poultry replacement of groundnut cake by palm kernel meal in broiler diets. Anim. Feed Sci. Technol., 16: 179-186.

Ott, L and Longnecker, M (2010). An Introduction to Statistical Methods and Data Analysis. Fifth edition. Vol. 1. R R Donnelley \& Sons, Inc./Willard (Carolyn Crockett; Ann.). p. 850-854.

Pántano, V; Spescha, L; Penalba, O and Murphy, G P (2013). Influencia de la variabilidad de temperatura y precipitación en la situación hídrica del suelo, en la región oriental de secano de la Argentina. Revista Meteorológica., 39: 21-36.

Rahim, M; Alimon, A R and Ivan, M (2010). Effects of fungal treatment on the in vitro digestion of palm kernel cake. Livestock Research for Rural Development. Vol. 22. Article \#82. http: / / www.lrrd.org/lrrd22/4/ rami22082. htm, accessed on 17 April 2014.

Romero, H; Ayala, I and Ruiz, R (2007). Ecofisiología de la palma de aceite. Revista Palma., 28: 176-184.

Sharmila, A; Alimon, A R; Azhar, K; Noor, H M and Samsudin, A A (2014). Improving nutritional values of palm kernel cake (PKC) as poultry feeds. Mal. J. Anim. Sci., 17: 1-18.

Urrueta, J (2009). Procesos Industriales. Segundo Congreso Nacional de Palma de Aceite. Palenque, Chiapas, México, Febrero 12 y 13 de 2009.
Van Soest, P; Robertson, J and Lewis, B (1991). Methods for dietary fibre, neutral detergent fibre and nonstarch polysaccharides in relation to animal nutrition. J. Dairy Sci., 74: 3582-3591.

Varela, M (2010). Boletín mensual de análisis sectorial de MIPymes. https://www.flacso. edu.ec / portal / pn Tem p / Page Master / y8vglufp6cnyudewphelq8muq0cozq.pdf, accessed on 14 Abril 2018.

Vargas, E (2000). Composición y variabilidad de los subproductos de trigo utilizadios en la alimentación en Costa Rica. Nutricion Animal Tropical., 6: 23-38.

Vargas, E and Zumbado, M (2003). Composición de los subproductos de la industrialización de la palma africana utilizados en la alimentación animal en Costa Rica. Agronomía Costarricense, 27: 7-18.

Vegas, A; Ortega, D; Gualoto, W; Paredes, E; Rebolledo, E; Quintero, L and Ortega, J (2016). Respuesta de la Palma Africana Hibrido INIAPTENERA Cultivada In Vitro según el Tipo de Explante y Niveles de Ácido Naftalenacético. Revista Bioagro., 28: 193-200.

Wing Keong, N (2005). Investigación sobre el uso de la torta de palmiste en alimentos para la acuicultura. Revistas Palmas, 26: 79-80.

Yeong, S W; Mukherjee, T K and Hutagalung, $R$ (1981). The nutritive value of palm kernel cake as a feedstuff for poultry. J. Dairy Sci., 74: 3582-3597.

Yeong, S W and Mukherjee, T K (1983). The effect of palm oil suplementation in palm kernel cake-based diets on the perfomance of broilers. Malays. Agric. Res. Dev. Inst., 11: 378-384. 